\title{
EKSISTENSI ANYAMAN PURUN SEBAGAI PENOPANG PEREKONOMIAN MASYARAKAT DI DESA HAUR GADING
}

\author{
Mardiana, Aima Jatul Salma, Noor Halimah, Sarijannah \\ Sekolah Tinggi Ilmu Alquran (STIQ) Amuntai
}

\begin{abstract}
Abstrak
Anyaman purun merupakan kerajinan anyaman yang dilestarikan secara turun temurun dari generasi kegenerasi oleh perempuan Desa Haur Gading.Kerajinan anyaman purun adalah salah satu aktivitas yang memberikan kontribusi besar dalam penyedian lapangan pekerjaan dan sudah ada sejak tabun kurang lebih 1978 dan semakin berkembang hingga sekarang.Keberadaan kerajinan anyaman purun ditopang oleh pengusaba atau para pengrajin kecil dan menengah serta para pekerja lainnya yang dikelola secara tradisional dan kini sebagian besar berbasis komputer.Penelitian ini bertujuan untuk. mengetahui bagaimana peran anyaman purun bagi masyarakat desa Haur Gadingdan perkembangan anyaman purun di desa Haur Gading. Penelitian ini menggunakan pendekatan kualitatif yang berlandaskan pada filsafat post-positivisme, Jenis penelitian mengunakan metode kualitatif deskreptif, serta prosedur pengumpulan data dengan observasi, wawancara dan dokumentasi. Hasil penelitian yang didapatkan peneliti, kerajinan anyaman purun di Desa Haur Gading sebelumnya banya dalam bentuk. bakul dan tikar purun, kini setelah para pengrajin bergabung dalam Sentra Anyaman Kelompok Maju Bersama Desa Haur Gading yang dibentuk pada Maret 2020, produk semakin beragam dan ramah lingkungan, seperti berbagai model tas purun, sendal hotel, vas bunga dan masib nyak lainnya sehingga permintaan konsumen meningkat, tidak hanya dibatas oleh daerah sekitar namun sudah menyebar di tingkat internasional.
\end{abstract}

Kata kunci : Eksistensi; Anyaman Purun; dan Ekonomi Masyarakat

\section{PENDAHULUAN}

Indonesia merupakan negara yang terkenal dengan berbagai macam penghasil produk kerajinan tangan yang bervariasi. Kecamatan Haur Gading Kabupaten Hulu Sungai Utara Kalimantan Selatan merupakan salah satu subsektor kerajinan, salah satunya adalah kerajinan anyaman purun. Kerajinan purun merupakan usaha kerajinan yang termasuk dalam usaha mikro, kecil dan menengah (UMKM) dimana banyak anggota masyarakat di daerah tersebut yang menjadikannya sebagai usaha rumah tangga untuk menopang ekonomi keluarga dan menjadi mata pencaharian sebagian besar masyarakat di pedesaan. Walaupun nilai jual dari produk ini tidak begitu tinggi namun keberadaannya menjadi penggerak perekonomian desa saat ini, dan menjadi produk yang diunggulkan daerah. Jika sektor ini dikelola 
dengan baik, Kabupaten Hulu Sungai Utara dapat menjadikan purun sebagai pendongkrak pembangunan ekonomi daerah. Karena, dilihat dari segi tenaga kerja, banyak tenaga kerja yang terserap pada subsektor ini dan bahan dasar purun cukup mudah diperoleh di daerah Kabupaten HSU dan sekitarnya. ${ }^{1}$

Terlebih lagi di Kecamatan Haur Gading terdapat beberapa Desa yang memiliki lahan gambut penghasil tumbuhan purun tersebut, diantaranya Desa Pulantani, Desa Tambak Sari Panji, Desa Teluk Haur, dan Desa Tuhuran. Setiap lahan purun di lahan gambut dimiliki oleh individual yang mana lahan tersebut merupakan warisan turun temurun dari nenek moyang, entah seperti apa sejarah orang dahulu sehingga lahan purun tersebut menjadi kepemilikan perorangan, tapi yang pasti setiap lahan sudah memiliki tanda batasan kepemilikan.

Adapun lahan-lahan purun tersebut bagi yang tidak mempunyai lahan pribadi. Keberdayaan dalam konteks masyarakat adalah kemampuan individu yang bersenyawa dalam masyarakat dan membangun keberdayaan masyarakat yang bersangkutan. Masyarakat yang sebagian besar anggotanya sehat fisik dan mental, terdidik dan kuat serta inovatif, tentu memiliki keberdayaan yang tinggi. Namun, selain nilai fisik, ada pula nilai-nilai intrinsik dalam masyarakat yang juga menjadi sumber keberdayaan seperti kekeluargaan, kegotong-royongan, kejuang- an, dan yang khas pada masyarakat Indonesia, yaitu kebhinekaan. Memberdayakan masyarakat adalah upaya untuk meningkatkan harkat dan martabat lapisan masyarakat Indonesia umumnya dan Masyarakat khususnya yang dalam kondisi sekarang tidak mampu melepaskan diri dari perangkap kemiskinan dan ketertinggalan. Dengan kata lain, memberdayakan adalah memampukan dan memandirikan masyarakat, seperti halnya pada daerah di Kabupaten Hulu Sungai Utara

\footnotetext{
${ }^{1}$ Rofiqah Wahdah dan Henny Septiana Amalia, "Pengembangan Daya Saing Produk Pada Sentra Kerajinan Purun Di Kabupaten hulu Sungai Utara Kalimantan selatan," Jurnal Spread 6, no. 2 (2016): 90.
} 
Tanaman purun banyak ditemukan di sekitar rawa-rawa Tumbuhan jenis ini mampu hidup bertahun-tahun dan banyak ditemukan di Kalimantan Selatan. ${ }^{2}$ Khususnya Desa Haur Gading dikreasi menjadi aneka kerajinan bernilai ekonomis. Balai Penelitian Kehutanan Palembang menyebutkan bahwa purun merupakan jenis Lepironia mucronata RICH yang bermanfaat sebagai bahan pokok kerajinan anyaman. Kerajinan anyaman yang dimaksud adalah tikar, bakul, tas, dan lain-lain yang memiliki nilai keindahan dan nilai jual di pasaran yang membuat 7 Desa di kecamatan Haur Gading menjadi sentra anyaman purun, salah satunya adalah Desa Haur Gading. Rosna dalam Aisyah menjelaskan bahwa anyaman adalah suatu keterampilan masyarakat dalam memproduksi suatu barang dengan teknik susup menyusup, tindih dan saling melipat antara pakan dan lungsing sehingga antara satu dengan lainnya menjadi kuat. ${ }^{3}$

Beberapa Desa di Kecamatan Haur Gading (Desa Pulantani, Tambak Sari Panji, Teluk Haur dan Tuhuran) merupakan desa gambut penghasil tanaman purun tersebut. Uniknya proses pembuatan aneka kerajinan tersebut dilakukan tanpa merusak alam. Alam benar-benar dijaga dan dirawat kelestariannya karena mampu memberi dampak sosial, ekonomi, dan budaya pada masyarakat setempat. Tradisi yang mampu menumbuhkan semangat gotong royong, kerjasama, dan kreativitas dan tetap terjaga. Di sentra kerajinan anyaman purun ini dproduksi dari berbagai bentuk produksi kerajinan purun. Kerajinan purun merupakan salah satu produk unggulan yang berbahan baku yang ada di Kecamatan Haur Gading.

Membuat kerajinan anyaman menjadi pekerjaan yang banyak ditemui pada beberapa daerah, salah satunya di Desa Haur Gading, Hulu Sungai Utara, Kalimantan

2 Raeno Rahmat Koestanto dan Mariani Yusuf Azis, "Kondisi Sosial Ekonomi Masyarakat Kampung Purun Kelurahan Palam," Frontier Agribisnis 4, no. 3 (2020): 1.

3 Aditya Novriyanata, Zainal Abidin, dan Adi Rahmadi, "Produktivitas Kerajinan Anyaman Purun Danau ( Lepironia Articulata Domin) Di Kelurahan Palam Kecamatan Cempaka Kota Banjar Baru Provinsi Kalimantan Selatan," Jurnal Sylva Scienteae 1, no. 2 (2018): 1. 
Selatan.Desa Haur Gading terbentuk atau berdiri tidak ada yang tahu pasti, diperkirakan terbentuk zaman penjajahan Belanda.Desa Haur Gading sekarang ini sudah dimekarkan menjadi 6 (enam) desa dan sekarang ini nama Haur Gading sudah menjadi sebuah kecamatan baru yang terpisah dari Kecamatan Amuntai Utara. Cerita pada masa dulu kata "Haur Gading" di ambil dari pohon "Haur" atau bambu yang banyak tumbuh di pesisir sungai. Karena bambu atau haur ini sangat kuat batangnya persis gading gajah, maka di sebutlah kata "Haur Gading" untuk member nama sebuah kampung atau Desa pada waktu itu sampai sekarang

Desa Haur Gading mempunyai jumlah penduduk sebanyak 455 orang yang terdiri dari laki laki 214 orang dan perempuan 241 dengan kepadatan penduduk 370 orang/Km dengan jumlah KK 168. Untuk lebih jelasnya dapat dilihat pada tabel berikut:

\begin{tabular}{|l|l|c|c|c|}
\hline \multirow{2}{*}{ No } & \multirow{2}{*}{ Uraian } & \multicolumn{2}{|c|}{ Jumlah } & \multirow{2}{*}{ Keterangan } \\
\cline { 3 - 4 } & Jumlah Penduduk & Laki-Laki & Perempuan & \\
\hline 1 & J & & 241 & \\
\hline
\end{tabular}

Adapun Tingkat Pendidikan Masyarakat Desa Haur Gading tingkat pendidikan masyarakat rata- rata berpendidikan tingkat SD dan sebagian kecil ada yang tamat SLTP dan SLTA.Di desa Haur Gading masih terdapat masyarakat yang buta huruf. Untuk jelasnya dapat dilihat pada tabel sebagai berikut:

\begin{tabular}{|l|l|l|l|}
\hline No. & Tingkat Pendidikan & Jumlah & Keterangan \\
\hline 1 & Buta Huruf & 30 & \\
\hline 2 & Tidak tamat SD & 200 & \\
\hline 3 & SD & 204 & \\
\hline 4 & SLTP & 120 & \\
\hline 5 & SLTA & 70 & \\
\hline 6 & Diploma/Sarjana & 18 & \\
\hline
\end{tabular}


Melihat fakta tentang tingkat pendidikan masyarakat yang masih rendah, sehingga berdampak pada jenis pekerjaan yang mampu di lakukan oleh masyarakatnya, seperti bertani, nelayan, dan pekerjaan utama para wanitanya yaitu menganyam purun, hampir $100 \%$ perempuan di desa haur gading bekerja sebagai penganyam purun untuk membantu perekonomian keluarga, tidak seperti bertani yang hanya dapat di lakukan ketika musim cocok tanam atau seperti nelayan yang hanya dapat mencari ikan ketika air sedang pasang, menganyam dapat dilakukan kapanpun di sepanjang tahun, hal itu lah yang membuat anyaman purun dapat di sebut sebagai penopang hidup ekonomi masyarakat.

Tabel mata pencaharian masyarakat Desa Haur Gading:

\begin{tabular}{|l|l|l|l|}
\hline No. & Mata Pencaharian & Jumlah & Keterangan \\
\hline 1 & Buruh Tani & 36 & \\
\hline 2 & Petani & 139 & \\
\hline 3 & Peternak & 20 & \\
\hline 4 & Pedagang & 20 & \\
\hline 5 & Pencari Ikan & 43 & \\
\hline 6 & Tukang Kayu & 8 & \\
\hline 7 & Penjahit & 5 & \\
\hline 8 & PNS & 5 & \\
\hline 9 & Pensiunan & - & \\
\hline 10 & TNI/Polri & - & \\
\hline 11 & Pengrajin Anyaman tikar & 250 & \\
\hline 12 & Lain-lain & 73 & \\
\hline & & & \\
\hline
\end{tabular}

Dan hampir semua lapisan masyarakat, apapun jenis pekerjaannya mereka juga menganyam purun dirumah setelah beraktivitas diluar dan saat pekerjaan mereka telah selesai. Misalnya seorang pedagang akan tetap menganyam ketika mereka memiliki waktu senggang, atau petani ketika mereka tidak bercocok tanam tentu menganyam menjadi sebuah alternatif untuk meningkatkan ekonomi keluarga.Para ibu-ibu

\section{1}


mengajarkan sedari dini, anak-anak meraka menganyam purun, sehingga hal tersebut tetap lestari dari generasi ke generasi.Membuat kerajinan anyaman menjadi pekerjaan yang banyak ditemui pada beberapa daerah, salah satunya di Desa Haur Gading, Hulu Sungai Utara, Kalimantan Selatan.Kecamatan Haur Gading terbentuk atau berdiri tidak ada yang tahu pasti, diperkirakan terbentuk zaman penjajahan Belanda.Desa Haur Gading sekarang ini sudah dimekarkan menjadi 6 (enam) desa dan sekarang ini nama Haur Gading sudah menjadi sebuah kecamatan baru yang terpisah dari Kecamatan Amuntai Utara.

Seiring perubahan zaman, industri kerajinan anyaman purun harus memiliki daya saing yang tinggi dalam menghadapi persaingan perdagangan internasional dengan demikian perlu adanya rantai nilai (value chair) yang efektif. Rantai nilai yang efektif merupakan kunci keunggulan kompetitif (competitive advantage) yang dapat menghasilkan nilai tambah (value added) bagi suatu industry. Persaingan bisnis yang semakin tinggi disebabkan oleh dampak globalisasi dan diberlakukannya perdagangan bebas sehingga menggeser paradigma bisnis dari comparative advantage menjadi competitive advantage. Tuntutan daya saing bisnis yang meningkat tingi akan meningkatkan ketahanan sebuah industri kerajinan. Hal ini membuat kegiatan bisnis atau perusahaan harus memilih strategi yang tepat atau strategis dan bisa beradaptasi dengan lingkungan yang terus mengalami perubahan. ${ }^{4}$

Berdasarkan hasil observasi lapangan dalam suatu kunjungan pada salah satu desa yakni desa Haur Gading yang berada di Kecamatan Haur Gading.Kecamatan Haur Gading terkenal dengan Setra produksi Anyaman purun dan mampu memberikan kontribusi yang besar bagi desa itu sendiri dan bagi daerah luar. Keberadaan kerajinan anyaman purun di kecamatan Haur Gading dalam perdagangan

\footnotetext{
4 Ratih Marina Kurniaty, Anas M.Fauzi, dan M. Achmad Chozin, "Daya Saing PT benar Flora Utama Berdasarkan Aktivitas Rantai Nilai Florikultura," Jurnal Manajemen dan Agribisnis 9, no. 3 (2012): 147.
} 
lokal maupun nasional mengalami pasang surut. Hal tersebut sebagian besar disebabkan oleh beberapa faktor yaitu strategi dan inovasi dari pengelola maupun pengarajin anyaman purun tersebut. berkaitan dengan inovasi, penggunaan bahan baku selain purun pengarajin juga memamfaatkan bahan lain seperti eceng gunduk untuk keperluan hiasan pada suatu produk kerajinan anyaman purun. Kerajinan anyaman purun ini memiliki kualitas yang tinggi sehingga memungkinkan untuk dapat berkompetensi dipasar nasional bahkan internasional. Industri kerajinan anyaman purun ini telah ada sejak tahun kurang lebih 1980-an yang dilakukan secara mandiri dan hasil jadi pun masih berbentuk sederhana dan hanya satu macam yaitu bentuk tikar purun.( hasil wawancara dengan kepada Ibu Noor Halimah sebagai pengurus kerajinan anyaman purun Desa Haur Gading) Seiring perkembangan dan tuntutan zaman lahirlah kelompok kerajinan anyaman purun yang dibina dan dikelola oleh pemerintah dan pengurus setempat sehingga keberadaan industri kerajinan anyaman purun masih tetap eksis dengan jumlah pengusaha 40 orang dengan berbagai tantagan yang dihadapi. Berdasarkan latar belakang diatas peniliti akan mendeskripsikan tentang "Eksistensi Anyaman Purun Sebagai Penopang Perekonomian Masyarakatdi Kecamatan Haur Gading”

\section{METODE PENELITIAN}

Penelitian ini dilaksanakan di Kecamatan Haur Gading kecamatan Haur Gading Kabupaten Hulu Sungai Utara Provinsi Kalimantan Selatan dengan Subjek dalam penelitian ini adalah kepala desa, pengurus anyaman purun, para pengarajin anyaman purun yakni para ibu-ibu rumah tangga dan perempuan remaja di Kecamatan Haur Gading. Adapun jenis penelitian yang digunakan dalam penelitian ini menggunakan metode penelitian deskriptif.Kualitatif ini sering disebut "metode penelitian naturalistik" karena penelitiannya dilakukan pada kondisi alamiah (natural sitting).Selain itu, metode kualitatif berupaya untuk menghasilkan keragaman 
singularitas yang terdapat pada peorangan, kelompok, masyarakat dan organisasi dalam kehidupan secara utuh, rinci, dan dapat dijelaskan secara ilmiah. ${ }^{5}$ Metodologi penelitian ini adalah suatu penelitian yang sistematis yang digunakan untuk mengkaji atau meneliti suatu objek pada latar alamiah tanpa ada manipulasi didalamnya. ${ }^{6}$ Metode yang dilakukan menggunakan metode dan pendekatan metode penelitian kualitatif. Metode kualitatif digunakan agar dapat menjawab pertanyaan penulis untuk melakukan ekplorasi lebih mendalam terhadap permasalahan yang terjadi.pos-tpositivistik memandang keadaan sosial sebagai sesuatu yang menyeluruh, menyesuaikan diri dengan keadaan, memilki arti yang mendalam dan hubungan kejadian yang bersifat saling aktif. ${ }^{7}$ Kualitas hasil penelitian dipengaruhi oleh dua hal yakni kebenaran instrument dan kebenaran prosedur pengumpulan data. Kualitas instrument penelitian berkenaan dengan validitas dan reliabilitas instrument dan kualitas pengumpulan data berkenaan ketepatan cara-cara yang digunakan adalah untuk mengumpulkan data ${ }^{8}$. Adapun prosedur pengumpulan data yang digunakan dalam penelitian ini yaitu dengan menggunakan wawancara mendalam kepada pemerintah desa yang memiliki wewenang dalam pembuatan kebijakan kepengurusan anyaman purun, kepada ketua dan anggota pengelolaan anayaman purun beserta masyarakat desa Haur Gading yang menjadi pengusaha atau pekerja anyaman purun desa Haur Gading kecamatan Haur Gading, observasi partisipatif, dan dokumentasi. Teknik analisis data dalam penelitian kualitatif ini adalah proses pengumpulan dan penyusunan data serta mencari pola atau tema untuk memahami maknanya. ${ }^{9}$ Proses mengelompokkan data berdasarkan

\footnotetext{
5 Sandu Siyoto dan M. Ali Sudik, Dasar Metodologi Penelitian (Yogyakarta: literasi Media Publishing, 2015), 27.

${ }^{6}$ Ide Gunawan dan Rusdiyanto, Prosiding The 2ND Internasional Seminar On Contemporary Islamic issues (Yogyakarta: Fakultas Ushuluddin Adab Dan Dakwah IAIN Manado, 2019), 294.

7 Sugiyono, Cara Mudah Menyusun: Skripsi, Tesis,dan Disertasi (Yogyakarta: Alfabeta, 2013), 24.

8 Sugiyono, Metodologi Penelitian Kuantitaif, Kualitatif, dan R\&D (Bandung: Alfabeta, 2016), 137.

9 Suwandra, I. W., Metodologi Penelitian Kualitatif dalam Ilmu Sosial, Pendidikan Kebudayaan, dan Keagamaan. . (Bandung: Nilacakra, 2018), 79.
} 
variabel dan jenis responden, mentabulasi data berdasarkan variabel dari keseluruhan respoden, menyajikan tiap variabel yang diteliti, melakukan perhitungan untuk menjawab rumusan masalah dan untuk menguji hipotesis yang diajukan. ${ }^{1}$

Dilihat dari segi penelitian kualitatif, teknik analisis data pada tahap ini terdiri dari tiga tahapan yakni mereduksi data, penyajian data, dan penarikan kesimpulan. Kemudia langkah terakhir yaitu peneliti mengecek keabsahan data teknik pemeriksaan data ini dilakukan untuk meminimalisir terjadinya kesalahan data yang dikumpulkan selama melakukan rangkaian penelitian dengan cara melakukan pengecekan kembali data yang sudah terkumpul dari berbagai sumber data. Menurut Sugiyono uji kredibilitas data atau kepercayaan terhadap data hasil penelitian kualitatif antara lain dilakukan dengan perpanjangan pengamatan, peningkatan ketekunan dalam penelitian, triangulasi, diskusi teman sejawat, analisis kasus negatif, dan mengulang melihat kembali (Sugiyono 2016, hlm. 270).

\section{HASIL DAN PEMBAHASAN}

\section{Ekologi Tumbuhan Purun}

Purun adalah tumbuhan endemik yang biasa tumbuh di daerah rawa. Jenis tumbuhan semakin mudah dijumpai dilahan-lahan gambut yang terdapat dibeberapa desa di Kecamatan Haur Gading seperti Desa Pulantani, Tambak Sari Panji, Teluk Haur dan Desa Tuhuran. ${ }^{1}$ Purun dapat tumbuh sepanjang tahun terutama untuk lahan yang selalu berair seperti tawar tepian sungai, atau saluran tersier. Kondisi ini terjadi karena purun tikus dapat beradaptasi pada lahan bersuhu masam. Tanah yang cocok untuk pertumbuhan purun tikus adalah tanah lempung atau humus dengan $\mathrm{pH}$ 6,9-7,3 tetapi juga mampu tumbuh dengan baik pada tanah masam. Pada daerah rawa misalnya

1 Sugiyono, Cara Mudah Menyusun: 9 kripsi, Tesis, dan Disertasi, 78.

1 Wasis Suprapto dan Nova Khrisha Yudha, "Purun: Merajut Ekologi Dan Tradisi Di Kota Tikar Dalam Konteks IPS,” PIPSI 4, no. 2 (2019): hal. 4.

65 
purun dapat ditemui pada ketinggian $0-1.350 \mathrm{~m}$ di atas permukaan laut. Purun tikus juga dapat tumbuh baik pada suhu $30-35^{\circ} \mathrm{C}$ dengan kelembapan tanah $98-100 \%$.

Tumbuhan ini mempunyai rimpang pendek dengan stolon memanjang berujung bulat gepeng, berwarna kecoklatan sampai hitam. Batang tegak, tidak bercabang, berwarna keabuan hingga hijau mengilap dengan panjang 50-200 cm dan tebal 2-8 mm. Daun mereduksi menjadi pelepah yang berbentuk buluh seperti membran yang menyelubungi pangkal batang, kadang-kadang dengan helaian daun ,ujung daun tidak simetris, berwarna coklat kemerahan sampai lembayung, tanpa lidah daun. Bunganya bulir majemuk, terletak pada ujung batang dengan panjang 2-6 cm dan lebar 3-6 mm, terdiri atas banyak buliran berbentuk silinder bersifat hermafrodit. Buah berbentuk bulat telursungsang, berwarna kuning mengilap sampai coklat. ${ }^{1}$
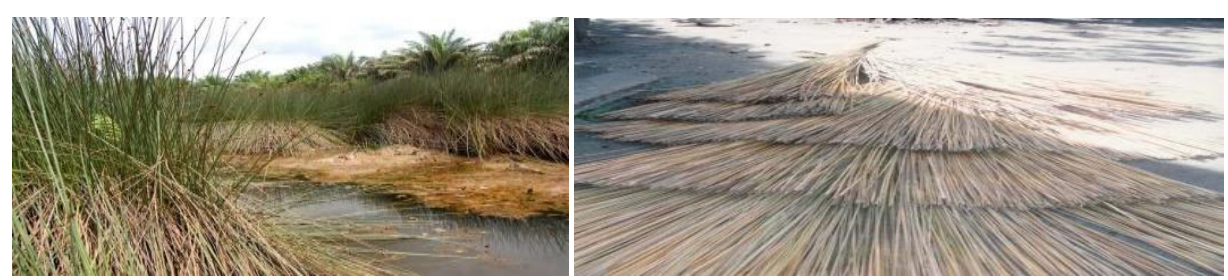

Pemanfaatan purun sebelum membahas lebih jauh tentang purun, penulis mencoba untuk mengkaji hasil alam yang dapat digunakan untuk menopang kehidupan umat manusia. Hasil alam dalam konteks ini adalah tumbuhan alami yang hidup di daerah rawa dan gambut. Tata \&Adi2016) menjelaskan pemanfaatan tumbuhan rawa dan gambut seperti pada tabel berikut ini:

1 Suprapto dan Khrisna Yudha, ha?. 48-49. 


\begin{tabular}{|c|c|c|}
\hline No & Manfaat & Pilihan jenis \\
\hline 1 & $\begin{array}{l}\text { Penghasil minyak (buah, sumber } \\
\text { karbohidrat, protein, bumbu, dan } \\
\text { lemak/minyak }\end{array}$ & $\begin{array}{l}\begin{array}{l}\text { Sagu, asam kandis, } \\
\text { pepaken, } \\
\text { manggakngangani, } \\
\text { kelakai, dan tengkawang }\end{array} \\
\text { kasturi, }\end{array}$ \\
\hline 2 & $\begin{array}{l}\text { Penghasil serat (substitusibahan baku } \\
\text { pulp dan kertas) }\end{array}$ & Geronggang, terentang, dangelam \\
\hline 3 & $\begin{array}{l}\text { Sumber bio-energi (woodpellet, } \\
\text { briket, bio-ethanol }\end{array}$ & Gelam, sagu, dan nipah \\
\hline 4 & Penghasil getah/lateks & Jelutung, nyatoh, dan sundi \\
\hline 5 & Sumber obat-obatan & Akar kuning, [pulai \\
\hline 6 & Hasil hutan ikutan lainnya & Gaharu, gemor, purun \\
\hline 7 & Kayu bernilai konservasi & $\begin{array}{l}\text { tikus, dan rotal irit } 7 \text { Kayu bernilai } \\
\text { konservasi Ramin dan merantimera }\end{array}$ \\
\hline
\end{tabular}

Mengacu pada tabel di atas terlihat ada tujuh kategori tumbuhan yang dapat dioptimalkan untuk kebutuhan manusia termasuk diantaranya purun. Purun adalah salah satu tumbuhan semak yang biasa ditemui di daerah rawa maupun tepian sungai. Tumbuhan jenis ini tumbuh di Pulau Sumatera maupun Kalimantan. Masyarakat di Provinsi Sumatera Selatan, Kalimantan Selatan, dan Kalimantan Tengah sengaja memelihara purun untuk dijadikan sebagai bahan utama anyaman, tikar, dan kerajinan tangan. Sementara menurut Asikin \& Thamrin, purun adalah tumbuhan pengendali hayati hama pengerek padi dengan cara memerangkap telur hama tersebut. Selain itu, purun juga dapat menyerap logam berat dan berperan sebagai bio-filter senayawa toksin yang larut dalam air.

Tumbuhan purun juga memiliki manfaat lain terutama jika dikaitkan dengan kegiatan sosial ekonomi masyarakat. Menurut Yoandestina purun dapat digunakan sebagai bahan baku untuk membuat tikar, topi, tas (bakul, kampil, anjat), alas kaki, alas piring makan dan sejenisnya. Tata \& Adi menambahkan di pasar tradisional Kalimantan Selatan tikar purun biasa dengan ukuran lebar $100 \mathrm{~cm} \times 150 \mathrm{~cm}$ dijual dengan harga $\mathrm{Rp}$ 20.000/lembar. Tikar warna ukuran $100 \mathrm{~cm}$ x $200 \mathrm{~cm}$ dijual 
dengan harga Rp. 30.000/lembar. Tas (map) berwarna dijual dengan harga 1.500/ lembar. Hal ini membuat masyarakat Kalimantan Selatan menjadikan purun sebagai mata pencaharian sampingan selain berkebun dan nelayan. Faktor-faktor yang menyebabkan banyak orang memilih bekerja sebagai pengrajin anyaman yaitu karena menganyam merupakan suatu pekerjaan yang dapat dikerjakan tanpa harus meninggalkan rumah tangga dan orang memilih menganyam untuk memamfatkan waktu senggang. ${ }^{1}$

3

\section{Penopang Industri Kerajinan Purun Purun desa Haur Gading}

\section{Pengusaha}

Kerajinan anyaman purun merupakan salah satu usaha kecil yang lakukan oleh masyarakat secara turun temurun masyarakat Kecamatan Haur Gading dengan sistem Tradisional. Dalam perkembangannya sebelum tahun 2018, para pengusaha melakukan secara mandiri tanpa bantuan pemerintah. Penopang eksistensi industri anyaman purun di Kecamatan Haur Gading salah satunya adalah pengusaha rumahan seperti ibu rumah tangga dan perempuan remaja. (hasil wawancara kepada pengurus kerajinan anyaman purun ibu Noor Halimah, 27 Maret 2021).

1 Irfandi, Adek Cerah Kurnia Aziz, dan Taufik Hidayat, "Optimalisasi Pendampingan Badan Usaha Milik Desa Kerajinan Anyaman Pandan Kabupaten Serdang Bedagai Sumatera Utara," Prosiding Seminar Nasional Pengabdian Kepada Masyarakat, 2020, hal. 38. 

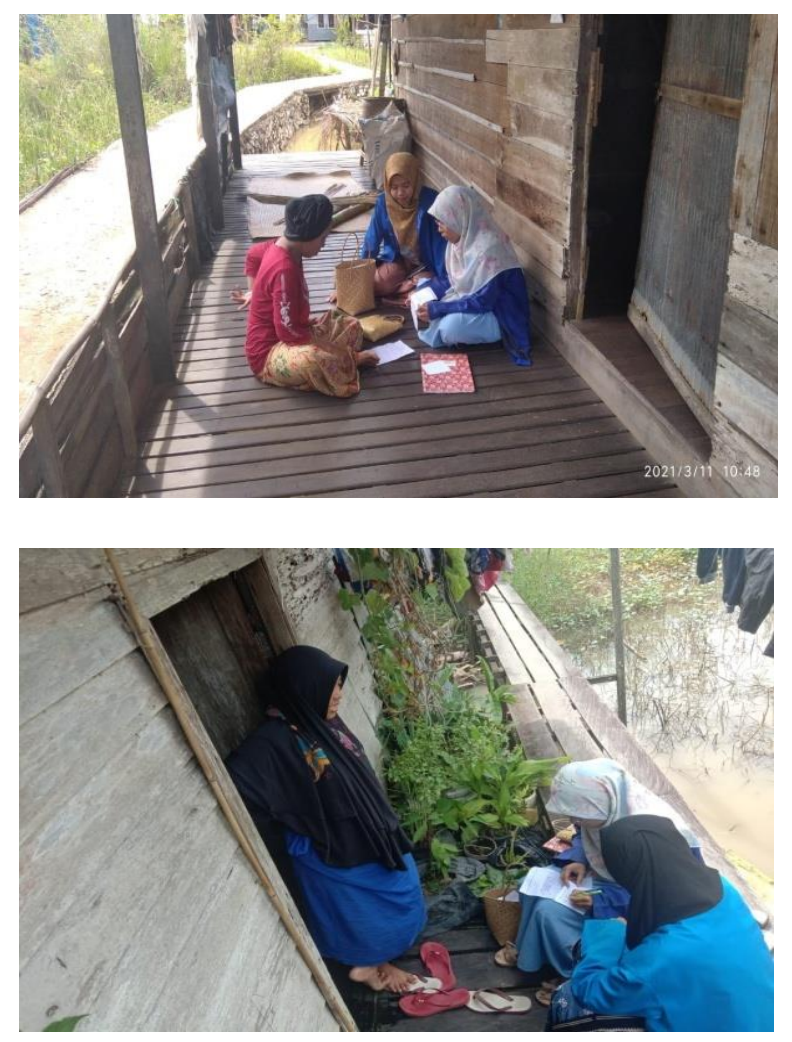

Berdasarkan hasil wawancara kepada masyarakat Haur Gading mereka menyatakan bahwa Perkembangan pengusaha kerajinan anyaman purun dipengaruhi oleh beberapa faktor yaitu, pertama dipengaruhi oleh keluarga karena pengusaha jenis ini meneruskan usaha keluarga. Kedua faktor lingkungan, Haur Gading mempunyai kekayaan alam yang melimpah yakni mempunyai lahan gambut sehingga tanaman purun dapat tumbuh dengan sendirinya tanpa bersusah payah untuk mencari bahan baku anyamn purun. Geografis yang serti itu mendorong pengusaha mendirikan usaha kerajinan anyaman purun. Ketiga, faktor ekonomi yaitu ingin meningkatkan kebutuhan ekonominya. Sebagian besar masyarakat khususnya wanita hanya mempunyai peluang mengayam karena potensi dan pengetahuan mereka lebih besar kepada kerajinan anyam purun selain itu memang anyaman purun tidak terlalu membutuhkan waktu 
yang lama sehingga sebagian besar lebih senang bekerja sebagai pengayam khususnya ibu rumah tangga. Kemudian pada tahun 2018 dari 18 desa yang ada di kecamatan haur gading terdapat satudesa yang sangat memiliki potensi dalam bidang lahan gambut dan pengelolaan sehingga menjadi contoh bagi desa-desa yang ada di Kecamatan Haur Gading seperti Desa Tambak Sari Panji, Teluk Haur, Tuhuran, Haur Gading, Jinggah Bujur, dan Keramat.

\section{Penerapan Manajemen Anyaman Purun}

Manajemen industri kerajinan anyaman purun rumahan dikelola langsung oleh pemilik usaha, tanpa bantuan dari orang lain. Pemilik usaha melakukan aktivitas menajemen mulai dari pembelian bahan baku, produksi, penjualan, keuangan, dan merekrut pekerja (Hasil wawancara dengan Ibu Fatmawati, 27 Maret 2021; Wardah 25 Maret 2021; Hj. Rusyidah, 27 Maret 2021; Waridah, 27 Maret 2021; Mali’ah,25 Maret 2021;) Persoalan yang dihadapi para pengrajin anyaman tersebut adalah ketika banyak pesanan yang menuntut ketepatan waktu penyelesaian.Selama ini pengelolaan usaha belum dilakukan secara baik.Oleh karena itu diperlukan sistem administrasi yang baik. Dengan manajemen yang baik maka akan mempermudah dalam pengambilan keputusan. Kebanyakan pengelolaan usaha skala kecil masih dilakukan secara tradisional, belum ada sistem administrasi dan sistem pengelolaan akuntansi yang berbasis komputer, sehingga mereka kesulitan dalam mengetahui perkembangan produk dan pengelolaan keuntungan dari hasil laba penjualan.

Namun sejak dibentuknya kelompok sentra kerajinan anyaman purun dibeberapa Desa di Kec Haur Gading dan salah satunya termasuk Desa Haur Gading yang dibentuk sejak Juli 2020, maka kerajinan anyaman purun mulai tersistem, baik dari segi kualitas bahan baku yang telah disortir ketat, atau dari kualitas anyaman para pengrajin, serta tersistemnya keuangan (kas) kelompok yang dikelola oleh bendahara kelompok anyaman yang sebelumnya telah diberi dana dari hasil pelatihan yang 
diadakan oleh pemerintah sebesar RP. 300.000, disini para pengurus kelompok harus bisa mencari cara untuk memasarkan produk mereka agar kas tersebut bertambah.

Adapun kelompok ini merupakan kelompok mandiri, yang keluar dari pada jajaran pemerintah desa, namun kelompok ini merupakan BUMDES ( Badan Usaha Milik Desa), dimana sebelumnya memang pemerintah Desa yang memfasilitasi, namun setelah pelatihan selesai, maka kelompok ini menjadi kelompok mandiri yang tidak terkait dengan unsur pemerintahan desa tersebut. Dan sebagai pilar dari kelompok anyaman adalah para pengurusnya, yang terdiri dari ketua, sekretaris, bendahara, dan quality control, dimana setiap pengurus berperan penting dalam kapasitas masing-masing, seperti contohnya quality control adalah orang yang menguji kualitass produk, baik dari segi pemilihan bahan baku, maupun kerapian anyaman, bendahara khusus mencata uang masuk dan keluar, serta dipertanggung jawabkan saat rapat evaluasi kelompok baik pengrajin maupun pengurus yang diadakan sekali sebulan. Sekretaris memiliki tugas mencatat pesanan anyaman dari anggota kelompok, berapa orang perbuah dalam mendapat pesana anyaman, dan pesanan bisa berupa bakul, tikar, tas, dan lain-lain.Para pengurus juga dibekali dengan skill pengelolaan kelompok, dimulai dari cara memanajemen sistem kerja kepengurusan, pengadmininstrasian keuangan kelompok, serta mengikuti seminar-seminar offline dan webinar cara pemasaran diform-form resmi seperti Tokopedia, Shoppee dan lain-lain.

\section{Bahan baku Kerajinan Anyaman Purun}

Bahan baku adalah syarat mutlak suatu produksi. Bahan baku dapat menentukan mutu dari suatu produk yan dihasilkan, oleh karena itu perlu adanya jaminan tersedianya bahan baku yang memenuhi persyaratan yaitu bermutu baik, mudah diperoleh dan ada dalam jumlah yang cukup. ${ }^{1}$ Bahan baku yang dipăkai pengrajin anyaman purun

1 Ernawati, Ratih Hurriyati, dan ${ }^{4}$ Puspo Dewi Dirgantari, "Strategi Pengembangan Kerajinan anyaman Purun Untuk Meningkatkan Daya Saing," Jurnal Ekonomu Modernisasi 17, no. 1 (2021): 32. 
dikampung purun adalah purun. Desa Haur Gading kabupaten Hulu Sungai Utara merupakan salah desa yang yang memfaatkan serat purun sebagai bahan pembuatan produk Tradisional. Selain menjadi petani, di desa ini hampir semua masyarakatnya mampu membuat kerajinan tradisional dari bahan dasar purun, tidak sedikit pula yang ahli sehingga menggantungkan hidupnya dari hasil menjual kerajinan purun. Purun adalah tumbuhan liar yang dapat beradaptasi dengan baik atau rawa pasang surut. Di lahan rawa kalimantan selatan, purun juga berfungsi sebagai inang alternatif hama dan tempat berlindung musuh alami, serta sebagai biopestesida, biofilter, biofer telezer dan bahan obat tradisional.

Purun merupakan tanaman perangkap bagi penggerek batang padi dan musuh alami seperti pridator dan parasitiot. Purun dapat tumbuh sepanjang tahun, terutama pada lahan yang selalu berair seperti tepi sungai dan saluran tersier. Purun adalah jenis rumput yang tumbuh pada lahan marginal yang tergenang air. Seperti yang terlihat digambar.(Christa Turang \& Alexander Octavianus Turang, 2021, hlm. 34) Bagi masyarakat yang memiliki lahan gambut baku dapat memperoleh langsung dari alam sedang masyarakat yang tidak memiliki lahan gambut dapat membeli baik dari lokal maupun diluar daerah atau kabupaten.

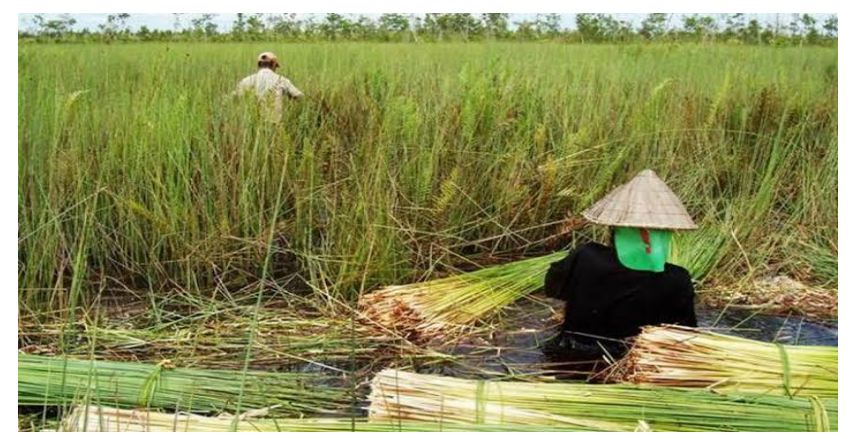




\section{Proses Produksi}

Purun merupakan salah satu bahan alam di kalimantan selatan yang dijadikan bahan utama pembuatan produk anyaman purun. Proses pembuatan dimulai dengan menyiapkan purun yang sudah melalui proses penumbukkan data pengeringan. Purun dipilah yang terbaik guna mendapatkan hasil anyaman yang bagus. Kemudian purun pilihan ini di anyaman satu persatu menyesuaikan bentuk tas tersebut sesuai dengan sketsa desain maka purun di anyam perlembar pola yang kemudian nanti disatukan dengan teknik jahit manual membentuk tas sesuai desain, maka lembaran pola anyaman purun yang sudah disesuaikan dengan ukuran pembagiannya, disatukan sesuai bentuk menggunakan teknik jahit manual menggunakan tali nilon.
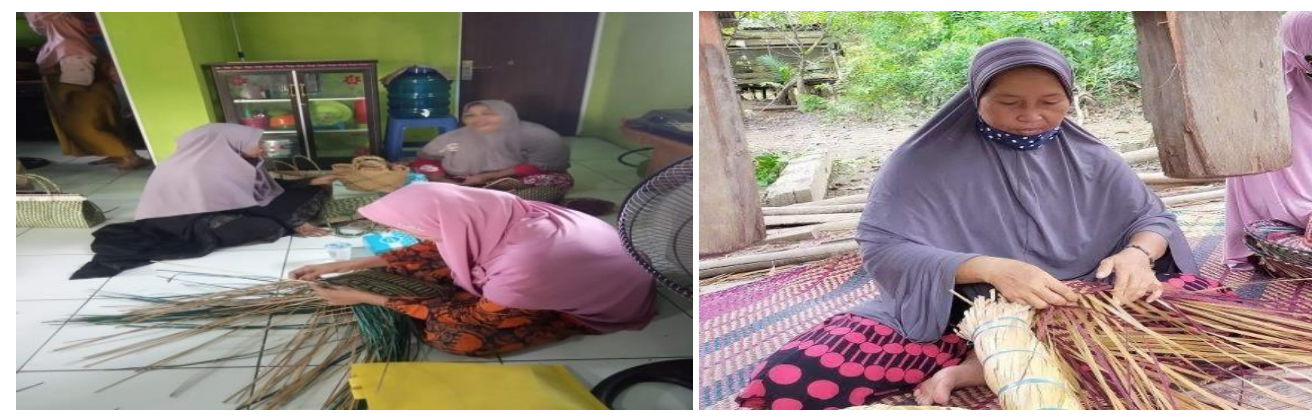

Setelah pola tas disatukan dan membentuk badan tas, kemudian dilakukan pemasangan kancing bagian depan. Kancing ini selain berfgungsi sebagai pengunci bagian tas tapi juga sebagai ornamen yang memperindah tampilan tas. Dibelakang tas dipasangkan tali yang sudah dikepang kecil terbuat dari bahan eceng gondok ataupun dari purun itu sendiri sebagai tali pengait kancing. Setelah bentuk tas selesai disatukan, selanjutnya masuk pada tahap membuat bagian tali sebagai bagian dari tas tali tas dibuat menggunakan bahan pendukung berupa eceng gondok tali tas terdiri dari dua bagian yang berbeda dan belakang tas dengan ukuran pendek, atau tali panjang disisi samping tas. Untuk mencapai tujuan dari kerajinan anyaman purun yang berkualitas 
maka fasillitator dari ke pengurusan mengadakan pelatihan dan pendampingan kepada pengrajin anyaman purun khas Haur Gading.

\section{Pemasaran produk kerajina purun}

Pemasaran merupakan kegiatan manusia yang diarahkan untuk memenuhi dan memuaskan kebutuhan serta keinginan melalui proses pertukaran barang atau jasa. ${ }^{1}$ Keberadaan produksi rumahan mampu memberikan pengaruh dan membawa perubahan pada kondisi sosial ekonomi masyarakat khususnya untuk Desa haur Gading baik yang berskala kecil, sedang maupun besar. adanya industri rumah/ home indunstri di suatu daerah mampu dalam meningkatkan volume perdagangan, penungkatan kegiatan pembangunan, peningkatan volume dan frekuensi lalu lintas uang dan barang-barang dari daerah tersebut atau pun penambahan jumlah pendapatan masyarakat. Setiap usaha yang bertujuan untuk melaksanakan fungsinya sebagai pencari laba harus mempertimbangkan setiap kegiatan yang penting dan mempunyai pengaruh besar terhadap keberhasilan usaha yang dilakukan seperti sistem pemasaran. Sistem pemasaran sangatlah penting dan memberi pengaruh besar untuk mengenalkan produk kepada masyarakat atau konsumen. ${ }^{1}$

Terdapat beberapa startegi yang digunakan oleh pengurus anyaman purun desa Haur Gading strategi yang mana definisi strategi adalah pola keputusan perusahaaan yang menentukan dan mengungkapkan sasaran, maksud dan tujuan yang menghasilkan kebijakan utama dan merencanakan pencapaian tujuan serta merinci jangkauan bisnis yang dikejar oleh perusahaan. ${ }^{1}$ Tujuan adanya strategi pemasaran untuk meningkatkan suatu produk atau jasa melalui usaha-usaha pemasaran yang lebih besar. Startegi ini

1 Fadel Retzen Lupi dan Nurdin, ${ }^{5 “ A n a l i s i s ~ S t r a t e g i ~ P e m a s a r a n ~ d a n ~ P e n j u a l a n ~ E-C 0 m m e r c e ~ P a d a ~}$ Tokopedia.Com," Jurnal Elek.tronik Sistem Informasi dan Komputer 2, no. 1 (2016): 21.

1 Novia Atzmaina, Farida Yuliarfai, dan Rina, "Analisis Strategi Promosi Terhadap Keputusan Pembelian Masyarakat Pada Kerajinan Purun AL-FIRDAUS BORNEO Banjar baru,” t.t., hlm. 2.

1 Lupi, "Analisis Strategi Pemasarah dan Penjualan E-C0mmerce Pada Tokopedia.Com," 21. 
dapat dilaksanakan bersama strategi lain untuk dapat menambah jumlah tenaga penjual, biaya iklan, meningkatkan untuk promosi penjualan. ${ }^{1}$

Startegi yang dilakukan oleh desa Haur Gading dalam memasarkan produk anyaman purun berbeda-beda dari setiap desa namun untuk sentra pemasaran utama tetap di himpun dan diketui oleh pengelola kepengurusan anyaman purun sebagai penaung kelompok kerajinan anyaman purun. Adapun startegi pemasaran yang dilaksanakan adalah dengan mempromosikan diberbagai sosial media, membangun relasi mitra kerja baik dari sektor pemerintahan maupun para influencer marketing, menjalin kerja sama dengan perusahaan swasta duanyam dari Jakarta sehingga dengan demikan tingkat penjualan dan permintaan dari konsumen semakin tinggi.(Hasil wawancara dengan ketua pengurus anyaman purun desa Haur Gading kepada Ibu Noor halimah, 27 Maret 2021)

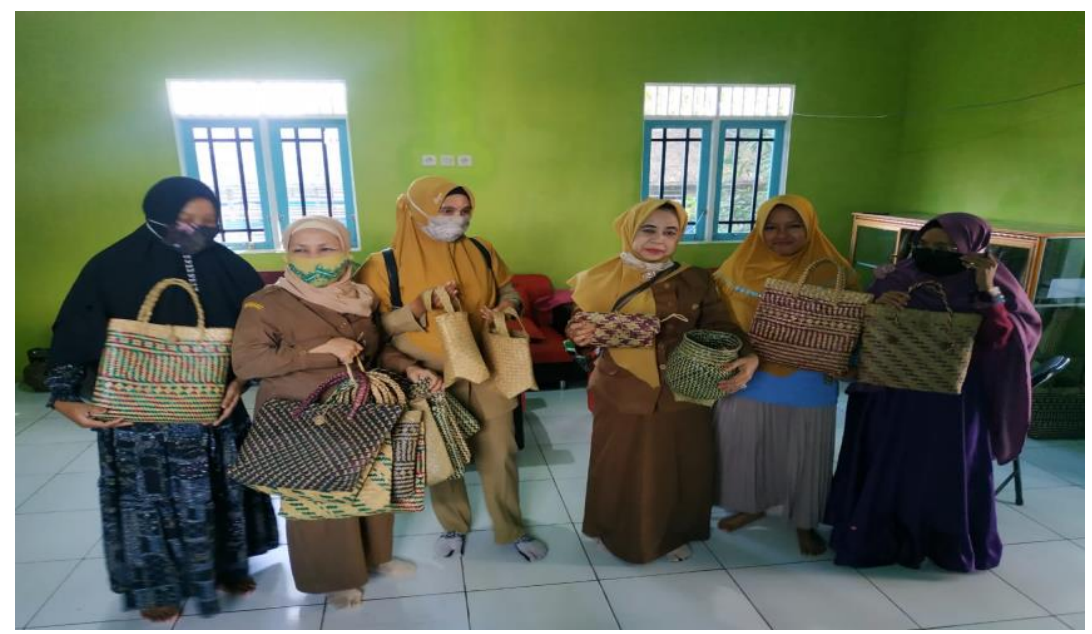

\section{Kendala Yang Di Hadapi}

Adapun kendala yang dihadapi oleh para pengrajin ayaman adalah susahnya menyortir bahan baku, sebab bahan baku purun sekarang ini tidak sebagus dahulu, dikarenakan

1 Hurriyati dan Dirgantari, “\$trategi Pengembangan Kerajinan anyaman Purun Untuk
Meningkatkan Daya Saing," 30. 
seringnya terjadi kebakaran lahan purun saat musim kemarau, yang membuat purunpurun tersebut sulit tumbuh kembali, dan juga banyaknya pembuangan limbah dari perusahaan yang mengalir dari sungai Tabalong sehingga mengganggu ekologi purun. Hal ini menyebabkan purun menjadi belang, diatas batang berwarna hijau dibawah batang berwarna merah, atau bisa juga ada bercak-bercak hitam yang menyebabkan hasil anyaman tidak elok dipandang. Tentu saja kendala dari bahan baku akan berpengaruh terhadap hasil anyaman, jika bahan baku tidak berkualitas tinggi maka otomastis barang akan dikembalikan tanpa diganti biaya produksi. Adapula kendala lain seperti proses penumbukan purun yang menyebakan purun menjadi pecah-pecah, sehingga membauan anyaman menjadi tercerabut. Serta kendala lain adalah kebiasaan menganyam dengan cara yang serampangan, sehingga mengahasilkan produk berkualitas rendah dari segi tingkat kerapian anyaman. Namun yang pasti kendala utama adalah tingginya harga bahan baku sehingga menyebakan pengrajin kewalahan, karena modal tidak sebanding dengan harga produk, terlebih para tengkulak seenaknya mempermainkan harga.

\section{Dukungan pemerintah}

Anyamanpurun merupakan pekerjaan utama wanita-wanita dibeberapa Desa Kecamatan Haur Gading, tujuh desa yang tergabung dalam kelompok sentra anyaman purun merupakan kesadaran pemerintah betapa perlunya meningkatkan skill pengrajin anyaman purun, baik dari segi kualitas kerapian, maupun dari kreativitas peningkatan inovasi produk anyaman. Pemerintah desa menyediakan fasilitas dan dana pelatihan yang dimana dana tersebut disisihkan dari dana APBD. Semangat pengrajin membuat pemerintah tidak ragu untuk memangkas anggaran desa yang telah tersusun untuk menunjang peningkatan skill tersebut. 


\section{SIMPULAN}

Industri kerajinan anyaman purun di desa telah berdiri dan berkembang selama puluhan tahun. Kemampuan masyarakat desa Haur Gading dalam melakukan kegiatan menganyam sudah dimilik sebelum industri kerajinan purun berdiri. Sejalan perkembangannya industri kerajina purun ditopang oleh pengusaha. Sebelum dibentuk industri kerajinan anyaman purun pengusaha menggunakan manajemen tradisional dan seiring perkembangan zaman mereka menggunakan manajemen modern. Dari aspek pemasaran, produk semula hanya melayani konsumen lokal kemudian berkembang pemasarannya keberbagai kota besar bahkan ketingkat internasional. Adapun produk yang dihasilkan berupa hasil penelitian yang didapatkan peneliti, kerajinan anyaman purun di Desa Haur Gading sebelumnya hanya dalam bentuk bakul dan tikar purun, kini setelah para pengrajin bergabung dalam Sentra Anyaman Kelompok Maju Bersama Desa Haur Gading yang dibentuk pada Maret 2018 semakin berkembang, dan mampu menghasilkan produk yang beragam dan ramah lingkungan, tidak hanya berbentuk tikar purun dan bakul serta topi namun kini hasil anyaman purun semaik kreatif seperti berbagai model tas purun, sendal hotel, vas bunga dan masih banyak lainnya.

\section{DAFTAR PUSTAKA}

Aditya Novriyanata, Zainal Abidin, dan Adi Rahmadi. "Produktivitas Kerajinan Anyaman Purun Danau (Lepironia Articulata Domin) Di Kelurahan Palam Kecamatan Cempaka Kota Banjar Baru Provinsi Kalimantan Selatan.” Jurnal Sylva Scienteae 1, no. 2 (2018).

Atzmaina, Novia, Farida Yulianti, dan Rina. “Analisis Strategi Promosi Terhadap Keputusan Pembelian Masyarakat Pada Kerajinan Purun AL-FIRDAUS BORNEO Banjar baru," t.t. 
Christa Turang, Widya, dan Daniel Alexander Octavianus Turang. "Pengembangan Desain Tas Wanita Berbahan Rumput Purun Menggunakan Metode ATUMICS." Jurnal Desain Produk (Pengetabuan Dan Perancanagan Produk) 4, no. 1 (2021).

Ernawati, Ratih Hurriyati, dan Puspo Dewi Dirgantari. "Strategi Pengembangan Kerajinan anyaman Purun Untuk Meningkatkan Daya Saing." Jurnal Ekonomu Modernisasi 17, no. 1 (2021).

Gunawan, Ide, dan Rusdiyanto. Prosiding The 2ND Internasional Seminar On Contemporary Islamic issues. Yogyakarta: Fakultas Ushuluddin Adab Dan Dakwah IAIN Manado, 2019.

Irfandi, Adek Cerah Kurnia Aziz, dan Taufik Hidayat. "Optimalisasi Pendampingan Badan Usaha Milik Desa Kerajinan Anyaman Pandan Kabupaten Serdang Bedagai Sumatera Utara." Prosiding Seminar Nasional Pengabdian Kepada Masyarakat, 2020.

Kurniaty, Ratih Marina, Anas M.Fauzi, dan M. Achmad Chozin. "Daya Saing PT benar Flora Utama Berdasarkan Aktivitas Rantai Nilai Florikultura." Jurnal Manajemen dan Agribisnis 9, no. 3 (2012).

Lupi, Fadel Retzen, dan Nurdin. "Analisis Strategi Pemasaran dan Penjualan ECOmmerce Pada Tokopedia.Com." Jurnal Elektronik Sistem Informasi dan Komputer 2, no. 1 (2016).

Metode Penelitian Kuantitatif, Kualitatif, dan R\&D. Bandung: Alfabeta, 2016.

Rahmat Koestanto, Raeno, dan Mariani Yusuf Azis. "Kondisi Sosial Ekonomi Masyarakat Kampung Purun Kelurahan Palam." Frontier Agribisnis 4, no. 3 (2020).

Siyoto, Sandu, dan M. Ali Sudik. Dasar Metodologi Penelitian. Yogyakarta: literasi Media Publishing, 2015.

Sugiyono. Cara Mudah Menyusun: Skripsi, Tesis,dan Disertasi. Yogyakarta: Alfabeta, 2013. 
- Metodologi Penelitian Kuantitaif, Kualitatif, dan R\&D. Bandung: Alfabeta, 2016.

Suprapto, Wasis, dan Nova Khrisna Yudha. "Purun: Merajut Ekologi Dan Tradisi Di Kota Tikar Dalam Konteks IPS.” PIPSI 4, no. 2 (2019).

Suwandra, I. W. Metodologi Penelitian Kualitatif dalam Ilmu Sosial, Pendidikan Kebudayaan, dan Keagamaan. . Bandung: Nilacakra, 2018.

Wahdah, Rofiqah, dan Henny Septiana Amalia. "Pengembangan Daya Saing Produk Pada Sentra Kerajinan Purun Di Kabupaten hulu Sungai Utara Kalimantan selatan.” Jurnal Spread 6, no. 2 (2016). 
Al-Khidma: Jurnal Pengabdian Masyarakat Vol 1 No 1 September 2021-Maret 2022 